\title{
EL HUMOR GRÁFICO DESDE UNA PERSPECTIVA RETÓRICA
}

\author{
Martha C. Chamorro Díaz
}

\begin{abstract}
Resumen
Normalmente los géneros de opinión devienen en textos argumentativos, puesto que el objetivo del autor es convencer al público sobre su modo de percibir la realidad, exponiendo sus puntos de vista. En este sentido, los chistes gráficos pueden ser herramientas de opinión, y por ello se basan tanto en el análisis gráfico como en el discursivo utilizando básicamente herramientas provenientes de la retórica, dado que las mismas están presentes en la instancia verbal y en la gráfica conformándose como elementos constructivos de la transmisión de pensamientos, puntos de vista y análisis de los acontecimientos.
\end{abstract}

\section{Palabras clave}

Retórica; humor; chiste; gráfico; prensa

\begin{abstract}
Normally the classes of thought turn into argumentative text, given that the author's objective is to convince the public of his or her way of perceiving reality, presenting his or her point of view. In this sense, graphic jokes can be tools of opinion and because of that, are based as much in the graphic analysis as in the discourse. Basically using tools based in rethoric, given that the same tools are present in the verbal and in the graphic, graphic jokes turn into constructive elements in the transmission of thoughts, points of view, and analysis of events.
\end{abstract}




\section{Key words}

Rhetoric; humor; joke; graphic; press

En el humor gráfico asoma más bien una cultura de la inteligencia de la imagen y de su relación con la palabra. (...) No son dibujos para ser contemplados como bellos objetos, pero pueden proporcionar el placer estético-intelectual de una metáfora lograda o un hallazgo expresivo e ingenioso que ilumina un objeto con una asociación inesperada y creativa. Es rápido, expresivo y locuaz. Ahorra palabras, pero puede decir mucho. Puede aclarar un asunto oscuro con más perspicacia y profundidad que un extenso artículo y, generalmente, con más gracia. Aunque la gracia no es preceptiva, suele tener la cortesía de decir las cosas de modo indirecto y jugando con los dobles sentidos para evitarnos el didactismo y la enfática seriedad de los discursos persuasivos. Rara vez renuncia a la polémica, a desmentir o desarticular lo comúnmente aceptado, pero elige un modo reflexivo de demolición, para que sea el propio lector quien se desmienta a sí mismo. (PEÑA-MARIN, 1996: 108)

\section{Hacia una nueva retórica}

No cabe ninguna duda de que el precursor del cambio en el campo de la Retórica ha sido Roman Jakobson, quien alrededor de los sesenta, procuró reformular los conceptos de metáfora y metonimia. (JAKOBSON, 1975: 347-395) En esta década también Barthes proponía un replanteamiento de la Retórica en términos de la lingüística estructural. Todorov, por su parte, daba cuenta de una red de conexiones entre la Retórica y los principios actuales que tratan de explicar cómo funcionan los textos. Para este último, el dominio de la Retórica es el discurso. Las tres relaciones que se presentan dentro de un texto literario (relaciones sintagmáticas, relaciones paradigmáticas y aspecto verbal) de acuerdo con su clasificación, tienen su correlato en la división 
establecida por la Retórica clásica (inventio, dispositio y elocutio). Mientras que a la inventio corresponde el dominio de la semántica, a la dispositio le compete el aspecto sintáctico y a la elocutio, el campo verbal.

Sin embargo, los autores citados conforman sólo el inicio de la renovación. Perelman introduce una propuesta innovadora: la recuperación de la retórica en su aspecto lógico, como el arte del buen pensar, en contraposición con el arte del buen decir, o la retórica del ornato. Desde esa perspectiva, la retórica se presenta como una lógica no formal y se desarrolla en la Teoría de la Argumentación.

Sucintamente serán descritos los aspectos principales de la Nueva Retórica. Ésta se define como "el estudio de las técnicas discursivas tendentes a provocar o acrecentar la adhesión de los espíritus a las tesis que se presentan a su asentimiento.” (PERELMAN, 1989: 7) De esta forma quedan expuestos los tres elementos que componen la relación retórica, o sea, el orador, el auditorio y el discurso. Es precisamente en este último donde se materializa el encuentro entre el orador y el auditorio, donde queda plasmado el éxito o el fracaso de la retórica. En este sentido, este modelo tiene como finalidad la búsqueda de adhesión.

El discurso retórico debe reunir ciertas condiciones previas: la realización de lo que Perelman denomina el "contacto intelectual” entre los participantes del discurso (esto es, el dominio de un lenguaje común, el conocimiento de las reglas de conversación, la atribución de valor a la adhesión del interlocutor y la disponibilidad a escuchar). (PERELMAN, OLBRECHT-TYTECA, 1989: 49 y ss) Para que el contacto efectivamente tenga lugar, es necesario captar la atención del interlocutor, de lo que se infiere que el orador debe tener cierto conocimiento previo del auditorio hacia el que se dirige, dependiendo de éste el éxito de la argumentación.

Siguiendo estos lineamientos, las imágenes simbólicas presentes en el humor gráfico componen textos que comentan asuntos conocidos por los lectores. Este conocimiento formaría parte del concepto contacto intelectual, al que se hizo mención, acuñado por Perelman. Bajtin considera que los textos son dialógicos, porque, al tematizar sobre cualquier asunto, el hablante lo encuentra ya siempre comentado por los anteriores discursos $\mathrm{y}$ ha de elegir entre los varios modos de considerarlo, lo que significa posicionarse respecto de los mismos y los grupos sociales y de los grupos sociales que profesan posturas diferentes. De esto se infiere que el receptor de un texto gráfico también realiza una elección y toma posición al respecto.

La imagen simbólica también posee los medios para recoger y mostrar las perspectivas, las maneras de concebir, valorar y sentir características de los diferentes sectores sociales respecto a un asunto presentado o aludido. 
Cabe destacar que si bien Perelman se concentra en la argumentación, consideramos que algunos de los conceptos por él vertidos, que toman como punto de partida a la Retórica clásica, pueden resultar de utilidad en este artículo.

Especial atención en la renovación retórica merece la propuesta del Grupo m, que realizó una muy buena sistematización de los recursos retóricos elocutivos y narrativos en un intento de Retórica General. La línea de investigación de este grupo vincula la Retórica con otras disciplinas cercanas, como la Lingüística, la Semiótica y la Poética, concentrándose en la teoría de las figuras del discurso.

Si como una de las definiciones tradicionales propuestas expresa que el objeto principal de la Retórica es el discurso persuasivo, el discurso argumentativo encuentra que las figuras (los procedimientos estilísticos) revisten de una gran importancia aún cuando se trate de discursos que no tengan como fin primordial el convencimiento o la persuasión. En este sentido, la cercanía de la Retórica con las funciones del lenguaje propuestas por Jakobson es innegable.

El Grupo m denomina a la función poética "función retórica”, tomando de ella la noción que sustenta el lenguaje artístico de ambos textos (el texto literario y el texto retórico), dependiendo el uso, únicamente, de la intencionalidad de su autor.

En la elocutio tiene lugar la ornamentación lingüística, conformada por las figuras y los tropos. El lenguaje es modificado a partir de una norma y se deberá determinar qué norma se seguirá para definir el desvío de la ornamentación lingüística que finalmente terminará en una norma (GRUPO M, 1977: 52 y ss). El ornatus es un componente decisivo, según Albaladejo, para “(...) la concreción de los fines del discurso retórico, que convergen en el delectare, docere y movere” (ALBALADEJO MAYORDOMO, 1991: 129), en la medida en que la elaboración artística elocutiva produce cierto deleite en el receptor del discurso, hecho que lo lleva a seguir el desarrollo del discurso con un tendencioso interés.

La Retórica general, de acuerdo con los postulados del mencionado grupo, debe proponerse el análisis de las técnicas de transformación del lenguaje, haciendo la distinción correspondiente entre las distintas especies y los objetos. El código lingüístico es modificado por quienes lo utilizan.

Para el Grupo m una metábola es "toda especie de cambio de un aspecto cualquiera del lenguaje” (GRUPO m, 1977: 62). La Retórica estudia las metábolas, o sea, las modificaciones en el lenguaje ejecutadas en virtud de la función retórica del lenguaje y del estilo, que persiguen como fin estético la literatura. Si bien el espacio de la elocutio ha sido el que ha sido estudiado con mayor rigor por parte de la Teoría Literaria actual, el aporte del Grupo m, contemporáneo al desarrollo de la 
Retórica moderna, no se reduce a ese nivel sino que se hace extensivo hacia otros ámbitos, como el discurso y las condiciones de producción del mismo, estudiadas por la Pragmática.

\subsection{Figuras retóricas}

La tradición retórica ha establecido una taxonomía de las categorías que se basaba en las cuatro operaciones lógicas: adición, supresión, variación del orden y sustitución. De acuerdo con Todorov, “desde Cicerón las figuras se definen por relación con algo distinto de ellas (...) se trata de teorías sustitutivas basadas en la posibilidad de establecer una equivalencia (semántica) entre dos significantes, uno propio, otro figurado”. (TODOROV, en AA.VV, 1970: 45)

Como ya se ha señalado, dentro de la elocutio se encuentra el ornatus, o la forma de embellecer el texto, y dentro de éste, las figuras retóricas. Se hará un recorrido por las algunas figuras retóricas con el pretexto de hacer una sistematización de las mismas, a los efectos de una mejor interpretación. Sin ánimo de incluirlas a todas, proponemos, dentro de cada categoría, algunas como ejemplo.

\subsection{Figuras fónicas}

Son aquellas que utilizan la materia sonora del lenguaje a través de la repetición de sonidos o de algún juego con las palabras. Mencionaremos algunos ejemplos: las onomatopeyas, las aliteraciones, las interjecciones, la paronomasia, el retruécano, la crasis, la epanalepsis, la epanadiplosis, la insistencia, entre otras.

\subsection{Figuras gramaticales}

Son aquellas figuras en las que prima una modificación de la organización lógica del lenguaje. Como ejemplo podemos citar la anáfora, la perífrasis, el eufemismo, la elipsis u omisión, la asíndeton, la enumeración, el hipérbaton, el paralelismo, la hipérbole, el paralelismo (sinonímico, antitético y sintético), el polípote, el polisíndeton, el quiasmo, la interclusio, las reiteraciones (derivación, políptoton, polisíndeton), el pleonasmo, la epífora.

\subsection{Figuras semánticas}

Dentro de esta categoría se distiguen dos grandes grupos de figuras que inciden profundamente en el sentido de la expresión: los tropos y las figuras del pensamiento. 
Los tropos conforman aquellos recursos en los que el sentido de una palabra se aparta de su contenido léxico originario hacia otro contenido léxico diferente. (LAUSBERG, 1983: 45 y ss) Como ejemplo podemos mencionar los que siguen: las metáforas (pura e impura), las metonimias, las sinécdoques, las comparaciones o símiles, las imágenes, las personificaciones, el oxímoron, los juegos de palabras (Retruécano, Calambur, Dilogía), la cosificación, la sinestesia, la senestesia.

Las figuras del pensamiento, a diferencia de los tropos, no llegan a implicar una sustitución. Afectan al modo de invención, la presentación de una idea, crean una relación inusual entre contenidos, o bien afectan a la relación entre las palabras y la realidad. Entre éstas se encuentran: la antítesis, la paradoja, la ironía, ${ }^{1}$ la antonimia, la anticipación, la polisemia, los eufemismos, la perífrasis, el apóstrofe, entre otras.

Otra clasificación agrupa a las figuras citadas de acuerdo con el siguiente criterio:

\begin{tabular}{|l|l|}
\hline Patéticas: & Hipérbole, prosopopeya, apóstrofe \\
\hline Lógicas: & Símil, antítesis, paradoja, sinestesia, gradación \\
\hline Oblicuas: & Perífrasis o circunloquio \\
\hline
\end{tabular}

\section{La imagen: Apuntes desde una perspectiva retórica}

Como punto de partida es preciso retomar un texto canónico -o fundacional, si se permite- que es "Retórica de la imagen”, de Roland Barthes ${ }^{2}$. Barthes elige como base de su estudio a la imagen publicitaria, debido a que ésta es claramente intencional, lo que configura a priori los significados del mensaje publicitario son determinados atributos del producto, y estos significados deben ser transmitidos con la mayor claridad posible. En este sentido, la imagen contiene signos.

No cabe ninguna duda de que la imagen presente en el chiste gráfico también es intencional. Barthes distingue tres tipos de mensajes en el texto publicitario: el mensaje lingüístico, el mensaje

\footnotetext{
${ }^{1}$ Estos recursos son muy utilizados en los chistes gráficos.

${ }^{2}$ Este texto de Roland Barthes puede ser considerado como un ejercicio, un ensayo semiológico en la etapa constitutiva de la disciplina. En pocas palabras, el punto de partida.
} 
icónico o la imagen denotada, y el mensaje plástico o la imagen connotada. La retórica, por lo tanto, conjuga dos niveles de lenguaje: un nivel de lenguaje propio y otro, de lenguaje figurado.

La iconografía publicitaria se compone de una multiplicidad de textos que se mezclan entre sí. La composición de la imagen publicitaria remite a un espacio cuyos límites y posibilidades corresponden a las exigencias mismas del género. Una gran cantidad de signos (gráficos, icónicos, cromáticos, etc.) se transgreden en este espacio en función de la imagen y del mensaje. Las figuras retóricas (consciente o inconscientemente) son las que permiten la interrelación de todos los signos que componen el espacio de la imagen. Esta última permite que la imagen logre los supuestos mundos, probables o improbables que describe.

La retórica de la imagen incluye "un conjunto de operaciones artificiosas que caracterizan el mensaje y buscan el asentamiento persuasivo y emotivo por parte de los receptores". (FONT, 1981: 18) Es en este mismo sentido que los textos periodísticos iconográficos comparten con la imagen publicitaria sus fines.

Para el Grupo m, "la retórica es la ciencia de los enunciados alotópicos o desviantes." (Grupo m, 1993: 263) Estas desviaciones retóricas se encuentran en los ejes que unen los elementos de un signo icónico: el eje significante-tipo y el eje significante-referente. Sólo se puede considerar una retórica en los ejes planteados: eje significante tipo (eje del reconocimiento) y significante referente (eje de la transformación).

La división da como resultado una retórica del reconocimiento (“retórica tipológica”) y una retórica de la transformación (“retórica transformativa”). La primera implica operaciones y operandos: mientras que las operaciones son supresiones, adjunciones, supresiones-adjunciones o permutaciones, los operandos son los tipos y los determinantes.

En lo que respecta al análisis retórico, para Durand, “toda figura retórica podrá analizarse así en la transgresión fingida a una norma (...) se tratará de las normas del lenguaje, de la moral, de la sociedad, de la lógica, del mundo físico, de la realidad, etc.” (DURAND, J, en AA.VV., 1972: 83)

Esto explica, entonces, las licencias que la publicidad toma con respecto a aspectos tales como la ortografía, la gramática, el humor intensivo, lo fantástico, entre otras cosas. Esto, de acuerdo con Durand, no es otra cosa que el ejercicio de la retórica. Si en la literatura las normas que se transgreden son las normas del lenguaje (del buen decir, de lo correcto), en la imagen, la transgresión remite a la realidad física, que es representada como distorsión. De esta manera, “la imagen retorizada, en su lectura inmediata, se emparenta con lo fantástico, el sueño, las 
alucinaciones: la metáfora se convierte en metamorfosis, la repetición en desdoblamiento, la hipérbole en gigantismo, la elipsis en levitación.” (DURAND, J, en AA.VV., 1972: 83)

Para el análisis de la imagen publicitaria, la gran cantidad de figuras retóricas clásicas existentes puede reducirse a un número escueto de operaciones: adjunción y supresión, si bien algunos teóricos consideran que se pueden agregar dos operaciones más, como la sustitución y el intercambio. (DURAND, J, en AA.VV., 1972: 84 y ss)

En cuanto a las relaciones a nivel paradigmático, dos proposiciones se podrían vincular mediante cuatro relaciones básicas: identidad, similitud, oposición y diferencia. (DURAND, J, en AA.VV., 1972: 85 y ss). Agrega, luego, las falsas homologías.

\section{El humor gráfico, fuente inagotable de riqueza expresiva y creatividad}

Para fortalecer la importancia del humor como variante del género opinativo, hay que tener presentes los elementos retóricos presentes tanto en el humor verbal como en el gráfico de manera habitual.

Hechas estas consideraciones, se puede inferir que la prensa tiene en el chiste gráfico un género de opinión elocuente. Por cierto, el mecanismo utilizado para verter dicha opinión rompe con lo convencional. Por medio de sus discursos breves, expresivos, y muchas veces convincentes, a través del humor se llega a cuestiones que de otra forma no podrían ser abordadas.

El humor rompe lo cotidiano al trasladar al receptor a un nuevo contexto, el creado por la situación recontextualizada que se presenta en el chiste. En este sentido, el chiste constituye un acto subversivo, que se revela contra el statu quo, mediante la ridiculización de personas o situaciones. Los chistes ponen de manifiesto situaciones insostenibles en el plano de los acontecimientos, en el plano real. Los chistes nos hacen reír cuando sacuden la seriedad y proporcionan un punto de vista novedoso sobre la realidad. En este sentido, los chistes son una opinión.

En épocas de crisis, la proliferación de caricaturas en la prensa gráfica es notable. Es innegable el lugar de la temática política dentro del género. La caricatura constituye un instrumento de lucha ideológica y crítica social. Por esta razón, encubre una crítica, y pone de manifiesto lo que no se podría decir de otra manera. Por medio de la caricatura se concreta la burla, ya que ésta es el medio apto para burlarse del poder, de la clase dirigente. 
La clase política siempre ha sido el blanco de la crítica y de las burlas, además de ser un ingrediente importante del humor, sobre todo cuando sus intereses distan de los del pueblo. Es en estos momentos cuando se intensifican las críticas.

El tema político es un componente fundamental de la sociedad. Las decisiones gubernamentales no siempre favorecen a todo el pueblo. Cuando se presenta este tipo de situaciones, entra en juego, por ejemplo, la caricatura.

Sin embargo, existen chistes que no son caricaturas, necesariamente, y que también tienen relación con el tema político. La cultura, la economía, la educación muchas veces giran en torno a la política, razón por la cual no debe extrañar que proliferen los chistes gráficos referidos a ellas.

Algunos chistes reflejan la vida cotidiana de las personas, sus hábitos, su forma de pensar y de actuar, sus profesiones, sus modas, sus defectos, sus creencias y valores, y, en general, su estilo de vida. Este tinte costumbrista se puede encontrar en algunas caricaturas. Es más, es frecuente encontrarlo en las caricaturas. Evora Tamayo la define como aquella que recoge las expresiones propias de un país, región, grupo étnico, “típicos en un momento típico también”. (TAMAYO, 1988: 11).

La finalidad que persiguen muchos chistes gráficos, en última instancia, es emitir un juicio o parecer, vale decir, una opinión. Ya sea cuando se critica, o bien cuando se expone un punto de vista sobre alguna cuestión.

A lo largo de la historia, los chistes gráficos han sido utilizados como medio de lucha y crítica religiosa, política o social. Es posible que el género que más haya sido utilizado con tales fines sea la caricatura. De acuerdo con Abreu,

“desde fines del siglo XVIII, esta forma expresiva ha sido usada como herramienta para ejercer presión social con una intención satírico-moralizante. También, para alertar al partidario o deprimir al enemigo en los conflictos políticos o bélicos. Por fin, ha devenido en un punzante instrumento político-social en las luchas partidistas contra el "stablishment"'” (ABREU, 2001)

Es común ver en los periódicos caricaturas que ponen en evidencia los desaciertos y los errores de los gobernantes, o que llegan más allá, poniéndolos en ridículo. Este género suele divulgar las equivocaciones de la clase dirigente. Con relativa frecuencia, la caricatura suele ser un poderoso instrumento de lucha ideológica, ya que por medio de ella, el emisor expone sus ideas sobre la realidad, en definitiva, opina, además de exponer sus valores y sus creencias, que quedan materializados en el mensaje icónico-verbal, de una forma admitida socialmente. El chiste gráfico da la oportunidad de plasmar un punto de vista que de otra manera sería imposible explicitar. Justamente, el género lo permite. 
A través de las caricaturas queda en evidencia una toma de posición sobre una cuestión determinada. Muchas veces se apunta a crear una conciencia social en el destinatario, por medio del ataque y la crítica tanto a personas como a instituciones, para lo cual necesita desenvolverse en un clima propicio de libertad de expresión. (ABREU, 2001)

En otras oportunidades la caricatura se convierte en un vehículo de denuncia, de protesta y encarna una lucha ideológica, a menudo virulenta. Al reírse de un personaje en un chiste, se lo está castigando, están siendo sancionadas sus deficiencias y muchas veces, el personaje es utilizado como caso ejemplar para los demás.

No es posible pensar en una caricatura "inocente", puesto que su pretensión es transmitir algo, y su mensaje la mayoría de las veces tiene contenido ideológico. Es preciso retomar la cuestión de la función social del chiste gráfico, en la medida en que lo cómico desarrolla su sentido dentro de un determinado contexto social.

De esta manera, es factible asegurar que al proceder con el análisis de diversos chistes que se desarrollan en el marco de una comunidad determinada, éstos ponen en evidencia sus valores, sus estilos de convivencia y también sus normas sociales.

\section{El humor desde una perspectiva retórica}

La primera referencia remite a Greimas, quien en 1966, en su Semántica General, abordó la temática del humor desde una perspectiva semiótica, al proponer que el efecto de sentido del humor es producto de las variaciones isotópicas. Greimas propone dos isotopías diferentes en un relato que se supone homogéneo. Además, las mismas se comunican por medio de un conector y la estructura del relato queda conformada de la siguiente manera: relato-presentación y diálogo.

Bueno y Blanco, en su Metodología del análisis semiótico, publicada en 1980, retoman la propuesta de Greimas al proponer que el chiste surge cuando el sentido da "un salto de isotopía (... ) el quiebre del sentido se produce porque la base clasemática, al llegar a un determinado momento del texto, se ve sustituida por otra, de orden totalmente distinto." (BUENO y BLANCO, 1980: 30). Sin embargo, quien sienta verdaderamente las bases para el abordaje del discurso humorístico es Violette Morin. De acuerdo con su propuesta, los chistes gráficos se pueden dividir en dos grandes grupos, conforme aludan al signo o al referente.

Es interesante la corrección que hace a la propuesta de Greimas (relato, presentación y diálogo), al proponer tres funciones: en primer lugar, la función de normalización, “(...) que pone en 
situación a los personajes (...) ”; en segundo lugar, una función locutora de armado (enclenchement), con o sin locutor, “ (...) que plantea el problema a resolver o el interrogante (...)” ; por último, una función interlocutora de disyunción, con o sin interlocutor, “(...) que resuelve “graciosamente” el problema o que responde “graciosamente” al interrogante." Esta última función desdobla al relato en "serio” y “cómico", y le proporciona a la secuencia narrativa, en términos de Morin, su existencia de "relato dislocado." (MORIN, en AA.VV., 1970: 121) En realidad, lo que está haciendo es precisar la existencia de tres constantes inalterables: FN (función de normalización), FA (función de armado) y FD (función disyuntora). La secuencia conformada por los tres elementos mencionados se construye como una forma paradigmática que algunas veces es fácilmente detectable.

Mientras que la función de normalización (FN) pone en situación a los personajes, la función locutora de armado (FA), ya sea con locutor o sin él, plantea el problema a resolver o el interrogante y la función interlocutora de disyunción (FD), la cual puede o no tener locutor, resuelve graciosamente el problema o responde, en su defecto, graciosamente el interrogante. Ésta última función puede bifurcar el relato en cómico/serio, confiriéndole a la secuencia narrativa la existencia de un relato dislocado.

Al igual que Greimas, parte del supuesto de que el texto se "bifurca" y que se produce un "choque de palabras" resultando un discurso "normal" y otro "dislocado". La bifurcación estará a cargo, siempre, de homonimias o polisemias de significantes o de significados.

El planteamiento de Morin es similar a la propuesta de Greimas con referencia a la relación entre dos relatos: ella propone la existencia de un “disyuntor”, “(...) con el que la historia así armada (normalización y locución) choca para girar tomando una dirección nueva y esperada.” (MORIN, en AA.VV., 1972: 122)

Además, la autora citada distingue distintos tipos de disyuntores, ya sean signos o referentes, de acuerdo con los que serán clasificados los relatos: relatos de disyunción semántica, cuando el disyuntor es un signo, y los relatos de disyunción referencial, cuando el disyuntor es un elemento al que se refieren los signos, o, lo que es lo mismo, un Referente.

La clasificación propuesta por la citada autora para los chistes está basada en las figuras polisémicas y homonímicas, es decir en la retórica clásica. Los esquemas que proponemos a continuación sintetizan los postulados sobre los cuales se enraíza su clasificación de las figuras de articulación:

\section{1) Figuras de articulación bloqueada}




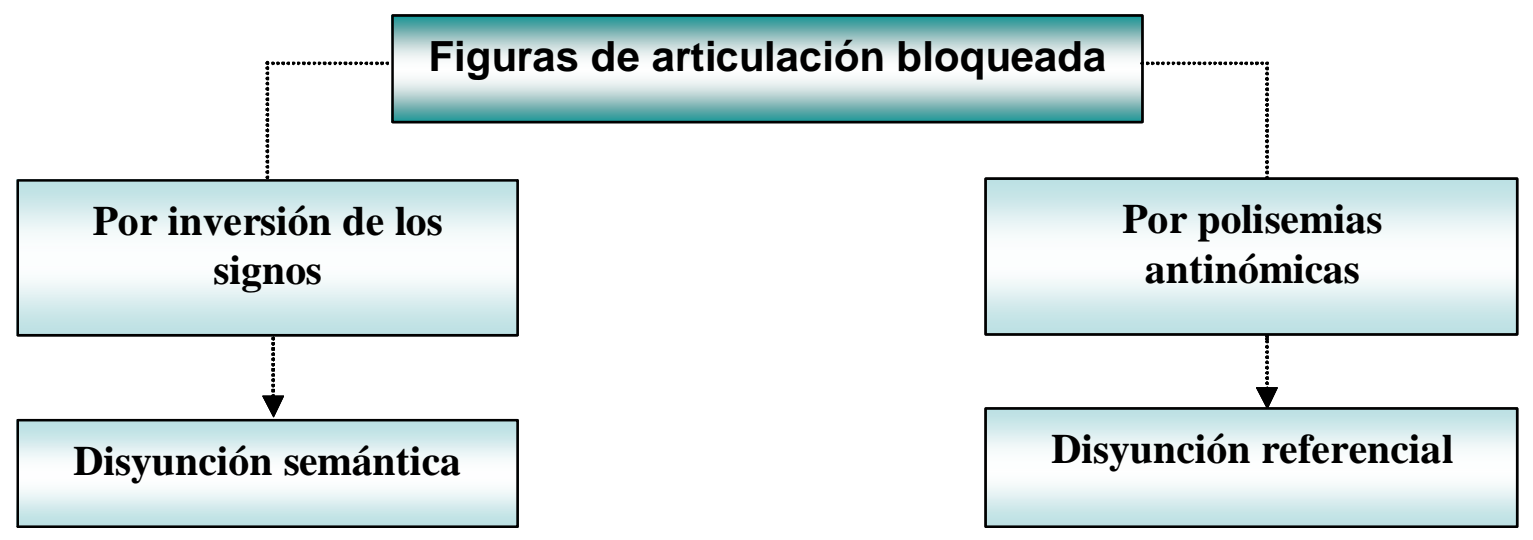

2) Figuras de articulación regresiva

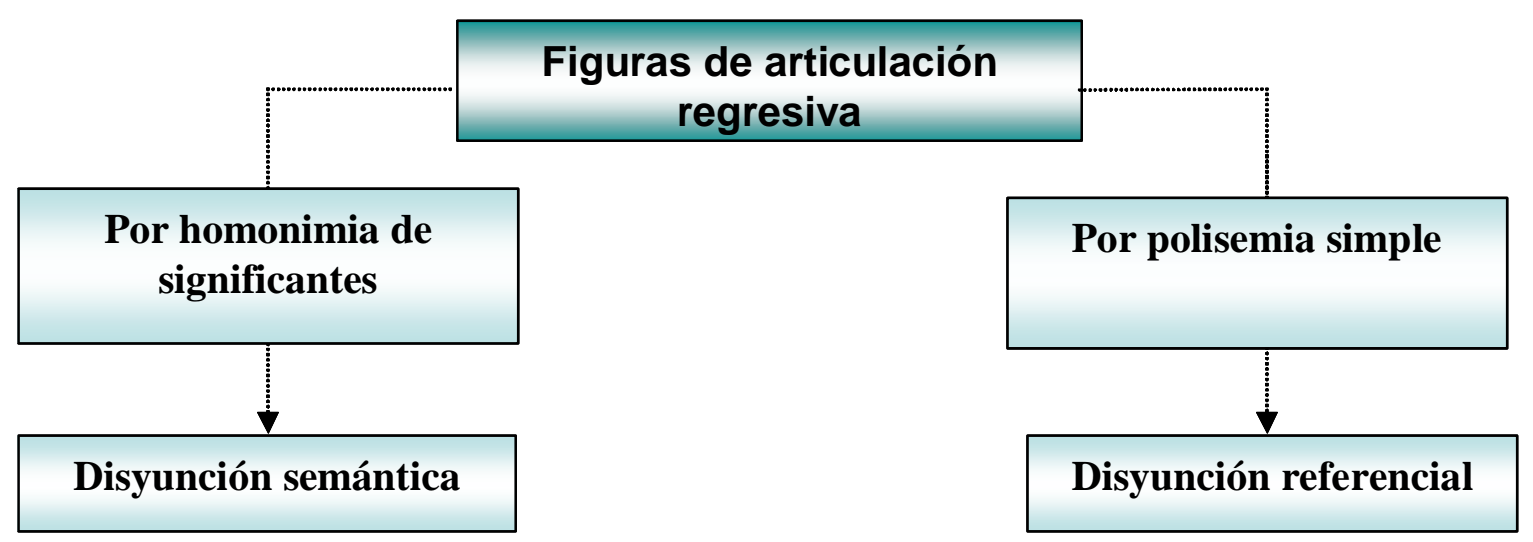

3) Figuras de articulación progresiva

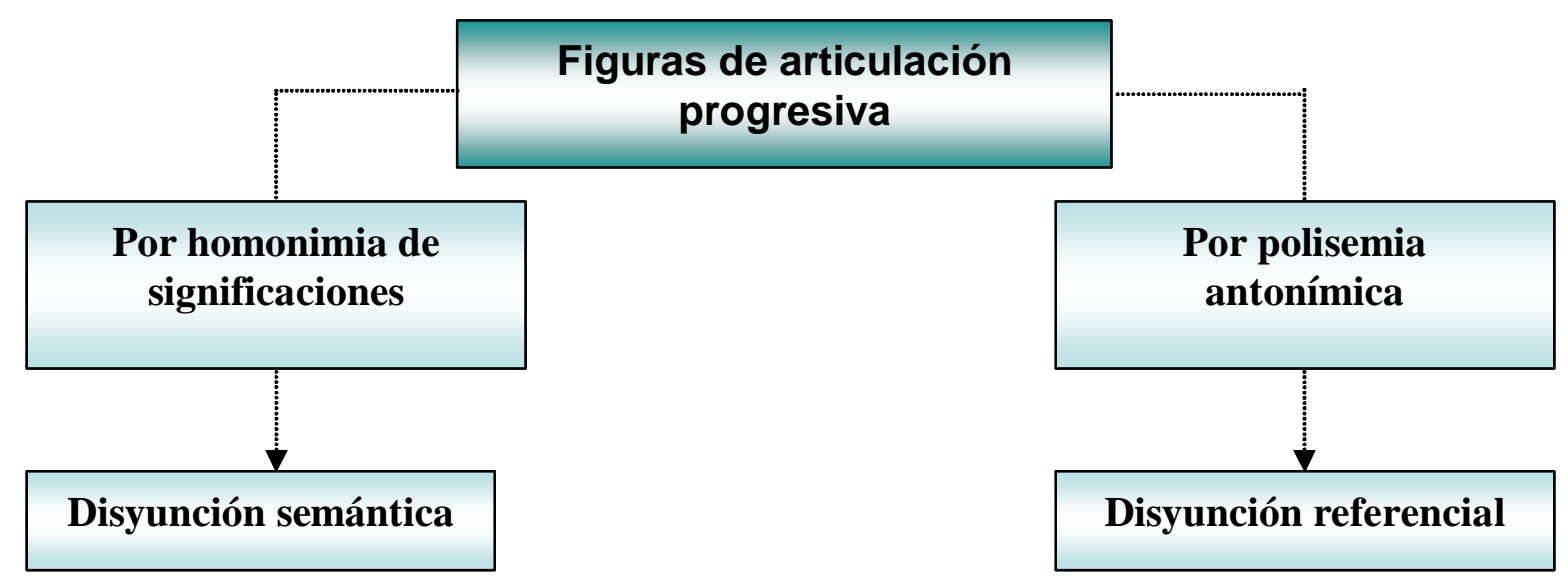

Fuente: Elaboración propia con base en los conceptos de Morin en AA.VV, 1970: 123-141. 


\section{El dibujo humorístico}

No existe un consenso acerca del alcance del término “dibujo humorístico”. La variedad terminológica y conceptual es tal que muchas veces “dibujo humorístico” es empleado indistintamente, a pesar de hacer referencia a una caricatura, por ejemplo. Los límites entre uno y uno no quedan del todo claros a la hora de establecer una clasificación que dé cuenta de las características inherentes a cada uno.

Violette Morin opta por considerar como “graciosos” en vez de "humorísticos” a varios dibujos extraídos de la prensa francesa, tomando como punto de referencia a las anomalías gráficas que proponen estos dibujos, en las cuales se puede reconocer la comicidad, es decir, ciertos rasgos o juegos de trazos que provocan rupturas de sentido, a las que llama “disyuntivas”, ya que sustentan un sistema que es capaz de desencadenar en la risa.

De acuerdo con la autora, "estas rupturas se disyuntan, de un trazo a otro del dibujo, por la yuxtaposición o la sucesión (diacronía narrativa, escalonada en varias figuras) de elementos sémicos incompatibles).” MORIN, V. en AA.VV., 1970: 137) La risa es provocada cuando las articulaciones alcanzan el límite de su unidad narrativa. Si el dibujo se encuentra fuera de este sistema, para Morin, se convierte “ (...) en el mejor de los casos, en un dibujo prosaicamente artístico.” (MORIN, V. en AA.VV., 1970: 137)

La citada autora sostiene, además, que “para imponerse como “gracioso”, el dibujo debe comprometer gráficamente la ruptura de su secuencia narrativa”. Es que lo gráfico está relacionado con lo escrito. La imagen, en algunos casos, es suficiente para presentar, en su superficie una disyunción completa. (MORIN, V. en AA.VV., 1970: 139)

El dibujo sin palabras tiene una mayor creatividad e invención de estilo que el dibujo que alterna con lo verbal: su comicidad está más realizada porque es enteramente visual, porque deslumbra al destinatario y lo sorprende. El dibujo, por sí solo puede restituir una disyunción, la cual puede tener contenidos sólidos acerca de determinadas prácticas de la realidad social, situaciones estereotípicas de la ciencia, los hábitos, la moda, las costumbres. Sin embargo, muchas veces la escritura compensa la falta de brillo en lo gráfico, y por medio de la instancia verbal le confiere mayor luminosidad.

Según Morin, los modos de complementariedad entre lo escrito y lo dibujado se pueden distribuir en tres grupos bien delimitados: en el primer grupo, se encuentran dibujos en los que la articulación disyuntiva deriva de la imagen, desplegándose allí técnicamente de un trazo a otro, sin que por ello medie disyunción alguna; un segundo grupo de dibujos presenta el esbozo de una 
disyunción, que se realiza de manera similar tanto en lo dibujado como en lo escrito; un tercer grupo, muestra la presencia de la disyunción que opera por superposición de dos secuencias paralelamente normales, una dibujada y la otra escrita.

Hechas estas consideraciones, trataremos de revisar las definiciones conocidas del dibujo humorístico, que escapan a la perspectiva de Morin. Una definición esclarecedora al respecto, a nuestro juicio, es la que proponen Natalia Díaz e Isabel Polito, para quienes el dibujo humorístico pone en evidencia "una determinada habilidad de visión de la realidad", la cual es presentada de manera tal que los demás puedan reír con ella. (DÍAZ, N. y POLITO, I. en ESTEVA-GRILLET, 1992: 38)

De la definición precedente se desprende que el dibujo humorístico muestra otro punto de vista de la realidad. Al mismo tiempo, de acuerdo con las autoras, tiende a hacer una evaluación de la realidad, al interpretarla, y en consecuencia, tiende a ser crítico.

Violette Morin, en el artículo citado precedentemente, tampoco establece una diferenciación entre dichas categorías, ya que sugiere, hacia el final de su análisis, que todos los textos analizados deberían ser considerados como "graciosos", en la medida en que esos dibujos divertidos corresponden a la ironía, a la sátira o al retruécano, sin manifestar ningún humor. Sin embargo, la conjunción de estos elementos, en tanto exponentes de las anomalías gráficas, será el desencadenante de la risa.

Son las anomalías gráficas las que, justamente, provocan las rupturas de sentido (“disyuntivas” en términos de Morin). Dentro de esta perspectiva, en una caricatura se produce una ruptura del sentido importante. El hecho de que a una persona se le represente con una cabeza desproporcionada en relación con su cuerpo hace suponer una "disyunción"; de hecho, para Morin, la caricatura de un personaje es el "grafismo disyuntivo básico". (MORIN, V. en AA.VV., 1970: 142)

Muchos elementos referenciados por la autora, como los retruécanos, la ironía, la sátira, entre otros, son propios de la caricatura. Ahora, ¿cuál es el límite entre éstos? ¿Existe una línea divisoria entre los distintos géneros del humor gráfico? La cuestión pareciera aclararse cuando Morin propone la definición de “chiste gráfico”, en el que el estilo del gráfico divierte al lector, al margen de la historia que se cuenta o de la disyunción que se produzca.

De lo expuesto hasta el momento se puede inferir que tanto el dibujo humorístico como la caricatura irrumpen en la ruptura de sentido. Morin suele emplear el término "caricatura” para sustentar su fundamentación sobre la disyunción en el dibujo humorístico. La cita que reproducimos a continuación sirve como ejemplo: 
"Las caricaturas de Lévine no necesitan escritura alguna para establecer disyunciones en los personajes más conocidos, así como las de Bosc y muchos otros bastan para disyuntir sin escritura alguna los rasgos de conyugalidad solidificados con el tiempo: infidelidades multipolares, aventuras masculinas caracteres desabridos femeninos..." (MORIN, en AA.VV., 1970: 139).

Algunos autores como Medina suelen denotar una marcada ambivalencia a la hora de establecer los límites entre el dibujo humorístico y la caricatura. Para Medina, el dibujo humorístico se caracteriza por la distorsión de sus elementos con el fin de acentuar las cualidades más representativas del tema en cuestión: "(...) Todo en el marco de la interacción entre la gracia, la ironía, lo alegre y lo triste que se reúnen para conseguir un efecto chistoso" (MEDINA, 1992: 13).

Los elementos propios de la caricatura, de acuerdo con el criterio de Medina, son los siguientes: distorsión, gracia, ironía, chiste. Además, considera que "el dibujo humorístico se encuentra ligado a la caricatura”, a la cual revaloriza porque tiene la facultad de expresar una opinión, por medio de su carácter satírico. (MEDINA, 1992: 15).

De esta manera, la expresión de la opinión, en una caricatura, se formaliza a través de la distorsión, a la que se añade el componente grotesco: "Se distorsionan y exageran ciertos rasgos para expresar claramente dicha opinión. Lo grotesco se combina con el ingenio para crear la caricatura”. (MEDINA, 1992: 15).

De las consideraciones de este autor surge que la caricatura es un género que pertenece a un género mayor, el dibujo humorístico. Además, establece una diferencia entre dibujo humorístico y caricatura, aunque los rasgos constitutivos de cada uno no logran ser expuestos con claridad, y en determinadas oportunidades el límite entre ambos es ambiguo: "la caricatura como tal es sólo uno de los posibles caminos que pueden tomar el dibujo de humor.” (MEDINA, 1992: 36).

De un modo un tanto generalizante cierra su trabajo expresando que el dibujo de humor traspasa los límites, en tanto género, de la caricatura y de todas las otras formas que le son propias: “todas las modalidades que le son propias; las abarca todas” ( MEDINA, 1992: 40).

\section{Humor gráfico, retórica, opinión y prensa}

Sin voluntad de cerrar aquí la cuestión abierta, expondremos en este punto las conclusiones que se derivan de la conjunción de los siguientes elementos: el humor gráfico, la retórica, la opinión y la prensa. Pretendemos ofrecer una visión en conjunto, la cual se deriva de los apartados precedentes. 
El humor gráfico contiene una serie de elementos propios de la actividad intelectual, cuya materia es la realidad. Ahora, ¿de qué manera puede ser abordada la realidad dentro de los límites del humor? ¿Cómo se puede decir aquello que está vedado? ¿De qué forma se puede manifestar la realidad a través de un chiste gráfico, el cual se construye como un texto más de opinión?

La Retórica es la herramienta más eficaz para dar respuesta a las preguntas precedentes. El chiste gráfico establece la posibilidad de la burla, de la crítica, de todo aquello que la realidad no permite hacer. La utilización de los recursos retóricos (tanto en el nivel gráfico como en el nivel verbal) potencia la capacidad descrita, que no es otra cosa más que la expresión de una determinada visión de los hechos, la puesta en ridículo, la búsqueda de nuevas significaciones que se desprenden de los nuevos efectos de sentido.

El humor constituye una excelente herramienta, a nuestro juicio, para la crítica, al permitir decirlo todo sin restricciones de ningún tipo. El humor desafía los límites del poder, de la dirigencia, de la realidad misma, y los aborda desde un lugar de privilegio: el del pensamiento crítico. Como se dice en chiste, está permitido.

Al margen de toda sanción, los chistes gráficos pueden emular críticas, violar reglas, opinar, tratar de persuadir, convencer, dar cuenta de una parte de la realidad, desenmascarar las hipocresías sociales.... Su poder es infinito.

El mayor riesgo del chiste gráfico es su exposición a la sanción y al juicio, que no siempre se funda en motivos constructivos, puesto que en su materialización quedan en evidencia todas las acciones arriba propuestas.

A esta altura, estamos en condiciones de afirmar que los chistes gráficos tienen un alto grado de influencia en la prensa. Al proponer una visión de la realidad novedosa, conforman una herramienta de opinión, de denuncia, de lucha.

Por todas las razones expuestas, los chistes gráficos tienen en la prensa la misma jerarquía que cualquier nota escrita, ya sea el Editorial, las notas de opinión o bien las notas de actualidad. Dada su importancia, no conforman textos de "segunda categoría” dentro del corpus de un periódico, en la medida en que ellos también dan cuenta de la realidad, la evalúan, la critican, la elogian, la ridiculizan, con una salvedad: su carácter gracioso, humorístico, es lo que lo permite.

Allí donde las demás texturas pueden titubear, los chistes gráficos emergen airosos para dar cuenta, desde su lugar, de lo mismo que dan cuenta los demás textos, pero con una diferencia: no les está vedado el recurso de la risa, que en definitiva, puede ser considerado como su fin último. 


\section{Bibliografía}

- $\quad$ ABREU, C. (2001) “Hacia una definición de caricatura.” En: Revista Latina de Comunicación Social, № 40, de La Laguna (Tenerife). El artículo se halla disponible en: http://www.ull.es/publicaciones/latina

- $\quad$ ALBALADEJO MAYORDOMO, T. (1991) Retórica. Madrid: Síntesis.

- $\quad$ DURAND, J. “Retórica e imagen publicitaria” (1972) Ed. Lumen. Contemporáneo.

- $\quad$ FONT, D. (1981). El poder de la imagen. Barcelona: Salvat Editores.

- $\quad$ GRUPO m. (1977) Rhétorique de la poésie. Bruselas: Complexe.

- $\quad$ GRUPO m. (1992) Tratado del signo visual. Para una retórica de la imagen. Madrid:

Cátedra.

- $\quad$ JAKOBSON, R. (1975) “Lingüística y Poética.” En: Ensayos de lingüística general, Barcelona-Caracas-México: Seix Barral. pp. 347-395.

- $\quad$ LAUSBERG, H. (1983) Elementos de retórica literaria. Madrid: Gredos.

- $\quad$ MEDINA, L. (1992). Comunicación, humor e imagen: Funciones didácticas del dibujo humorístico. México: Editorial Trillas.

- $\quad$ MORIN, V. (1970) “El chiste”. En: AA.VV. Análisis estructural del relato. Buenos Aires: Editorial Tiempo Contemporáneo. Versión de Beatriz Dorriots.

- $\quad$ MORIN, V. (1972) “El dibujo humorístico”. En AA.VV: Análisis de las imágenes. Buenos Aires: Editorial Tiempo Contemporáneo.

- $\quad$ PERELMAN, CH. (1989) Traité de l'argume ntation, p. 5; “Introducción”, a Eléments d'une théorie de l'argumentation, Presses Universitaires de Bruxelles, Bruselas, 1968, p. 7.

PERELMAN, OLBRECHT-TYTECA, L. (1989). Tratado de la argumentación: la nueva retórica. Madrid: Gredos. Versión en español.

- $\quad$ TODOROV, T. (1970) “Sinécdoques”. En: Investigaciones retóricas II. Buenos Aires: Ediciones Buenos Aires. 